\title{
Divine impoliteness: How Arabs negotiate Islamic moral order on Twitter
}

\author{
Najma Al Zidjaly \\ Department of English Language and Literature, \\ College of Arts \& Social Sciences, \\ Sultan Qaboos University \\ P. O. Box. 42, Seeb, Oman
}

\begin{abstract}
In this paper, I examine impoliteness-oriented discourse on Arabic Twitter as a resource for the negotiation of Islamic moral order. I do so by highlighting the responses Arabs post in reaction to a tweet which attacks Islamic cultural face. As the triggering act poses an indirect request to change an authoritative Islamic practice deemed immoral by the instigator of the tweet, sundry responses were generated to repair the damaged collective face through keeping intact or arguing against the questionable moral order. The main strategy I identify as a response to the professed face-attack is divine (im)politeness, intertextually referencing religious texts in favor of (or against) the existing (im)moral order. The rites of moral aggression also draw upon questions, provocation, personal attacks and projection of Islamic behavior onto unaddressed third parties (e.g., Christians and Hindus). The findings capture one moment of a historic shift in Islamic moral order and the role that impoliteness plays in digital Arabic contexts.
\end{abstract}

Keywords: Impoliteness, moral order, Twitter, Arab identity, intertextuality, authoritative texts, cultural face, rites of moral aggression

For citation:

Al Zidjaly, Najma (2019). Divine impoliteness: How Arabs negotiate Islamic moral order on Twitter. Russian Journal of Linguistics, 23 (4), 1039 - 1064. doi: 10.22363/2312-9182-2019-23-4-1039-1064.

\section{«Божественная невежливость»: как арабы обсуждают исламский моральный порядок в Твиттере}

\author{
Наджма Аль Зиджали \\ Университет имени султана Кабуса, Оман \\ P. О. Вох. 42, Сиб, Оман
}

\section{Аннотация}

В статье проанализированы дискурсивные особенности дискуссий на тему исламского морального порядка, которые ведутся в арабском Твиттере и часто носят невежливый характер. Особое внимание уделяется отдельным высказываниям арабов, которые опубликованы в ответ на записи в Твиттере, 
смысл которых сводится к критике традиционного исламского общества. Поскольку инициирующий акт содержит косвенный запрос на изменение официальных исламских практик (традиций), которые инициатор твита считает аморальными, они вызывает ответные реакции, нацеленные на восстановление морального урона, нанесенного исламскому обществу. Было выявлено, что оно ведется не через прямую аргументацию, а при помощи косвенных приемов, основным из которых является интертекстуальность, ссылки на религиозные тексты, поддерживающие или осуждающие существующий порядок. Отмечено, что моральная агрессия осуществляется в виде провокационных вопросов, личных нападок и проецирования исламского поведения на третьи стороны (например, христиан и индусов). Результаты исследования свидетельствуют об историческом сдвиге в исламском моральном (нравственном) порядке и той роли, которую невежливость играет в цифровой коммуникации.

Ключевые слова: невежливость, нравственный порядок, Твиттер, арабская идентичность, интертекстуальность, авторитетныле текстьл, моральная агрессия

\section{Для цитирования:}

Al Zidjaly, Najma (2019). Divine impoliteness: How Arabs negotiate Islamic moral order on Twitter. Russian Journal of Linguistics, 23 (4), 1039 - 1064. doi: 10.22363/2312-9182-2019-23-4-1039-1064.

\section{Introduction}

Within Arabic Islamic contexts, technology is found at the center of social and religious activism. Examples include Omanis' use of cassette tapes to disseminate religious sermons to the masses in the 1980s (Eickelman 1989), young women's use of mobile technology in the Arabian Gulf to challenge Arab gender norms in the 1990s (Al Zidjaly and Gordon 2012), Arabs's Habermasian digital religious and political debates in the 2000s (Eickleman and Anderson 2003), and their appropriation of Yahoo chatrooms and the WhatsApp chatting messenger to revisit sociocultural concerns and reconstruct Arab identity from the bottom up (Al Zidjaly 2010, 2014, 2017a). Across these examples and platforms, Arabs have continually, creatively, and surreptitiously used emerging technologies to circumvent their society's limits on free expression and enact political and social activism (KhosraviNik and Sarkhoh 2017; Nordenson 2018; Sinatora 2019a, 2019b; Sumiala and Korpiola 2017; Zayani 2018). Therefore, as demonstrated by my decade-long ethnographic examination of Arab identity on social media, from the inception of new media technology (and, in particular, Yahoo chatrooms), Arabs have appropriated social media platforms as a tool to incite social and political change by turning traditionally nonnegotiable discourses into ones which are open for discussion (see Al Zidjaly 2010, 2012, 2019a, 2019b, 2020). Further examining the extent of such activities would help fill a critical gap in digital discourse research, given the centrality of Arab identity to international concerns (Nordenson 2018) and the complexity of Arab identity based on religion (versus language or geography; Lewis 2001).

In this paper, I explore the linguistic strategies used by a group of Arabs on Twitter in responding to an aggravating tweet that questions a ubiquitous cultural practice. To do so, I build on research that has identified the role that intertextual references play in facework and identity negotiation in digital Arabic contexts (Al Zidjaly 2010, 2012, 2017b, 2019a; Badarneh 2019; Badarneh and Migdadi 2018; Labben 2018) ${ }^{1}$. Specifically, I draw

${ }^{1}$ Intertextuality has been identified as key to Arabic digital activism (Al Zidjaly 2010, 2017b, 2019a, 2020). 
upon a relational approach toward impoliteness (Locher and Watts 2005) and the concept of moral order (Kádár 2017a), defined as situated cultural norms (Graham 2018) or a set of ideas and beliefs arranged into an ordered whole or ritualistic practice. I additionally examine the following research questions: How does a group of Arabs respond to public cultural face-attacks, especially at a time when the Muslim identity is undergoing local and global debate? How do they digitally negotiate Islamic moral order? What role does impoliteness and facework play in shifting Islamic intersubjectivity on Twitter?

\section{Background}

\subsection{Impoliteness, relational work and the moral order}

Impoliteness as a linguistic lens to examine aggravation-oriented pragmatic variation has undergone two major shifts ${ }^{2}$. The first shift was a natural consequence of the relational, discursive turn the general field of Politeness Studies underwent, as led by Watts (2003), Locher (2006) and Locher and Watts (2005). Accordingly, binary face-enhancing and face-threatening data were replaced with discourses that include disagreeable to acrimonic behavior, which, according to Locher and Bolander (2017), established the importance of face (Goffman 1967) to impoliteness research, although facework was conceptualized broadly. The interrelation between face and impoliteness research proved especially beneficial in interpersonal pragmatics, an approach developed by Locher and Graham (2010) that foregrounds the creation of relationships through interaction. Graham and Hardaker (2017: 786) posited that interpersonal pragmatics is particularly important for digital interaction because of its focus on "the ways that interactants interpret and use their understandings of (im)politeness in given digital contexts to regulate their identities and interactional choices within emergent discourse". In this view, impoliteness is not only an interactive phenomenon, but also an interpersonally and culturally embedded social practice. Locher (2015) further noted that the first shift opened the academic field of impoliteness to multidisciplinary approaches and methodologies, especially identity construction research (for more on impoliteness and identity construction, see Garcés-Conejos Blitvich 2018).

The second shift was adopted by a slightly smaller group and concerned the moral order. As moral order consists of a "cluster of social and personal values that underlie people's production and interpretation of (im)polite action”, Kádár (2017a; xii) argued that investigating impoliteness requires peering into the perception of morality and interpersonal relationships within the broader context and rituals in which they are based. A ritual, in particular, can trigger polite or impolite evaluations, as rituals maintain the order of things and tend to imply a moral stance (Kádár 2017a). Consequently, some scholars have retheorized impoliteness as a matter of morality (Haugh 2015, 2018; Kádár 2017a; Kádár and Haugh 2013; Xie 2011, 2018; Xie et al 2005).

The relational, identity, and moral aspects of impoliteness highlight the complexity involved in impoliteness research, as argued by Xie (2018) in his introduction to a special

2 Although Bou-Franch and Garcés-Conejos Blitvich (2018) argued the existence of a third multimodal shift, studies of impoliteness have always included various modes. 
issue dedicated to examining the multifaceted interrelation between moral order, digital discourse and different types of impolite-oriented interactions. Three key studies from the special issue merit mention, as they depict the many ways identity is explored through impoliteness. First, Reiter and Orthaber's (2018) study of Slovenian commuters' impolite expression of moral indignation on Facebook against bus drivers highlights a historic moment of socioeconomic change that legitimates moral relativity in times of unrest. Second, Georgakopoulou and Vasilaki's (2018) demonstration of impoliteness as a resource for restoring the moral order of a specific group constructs impoliteness as a tool to accentuate group identity ${ }^{3}$. Third, Sinkeviciute's (2018) take on the relationship between impoliteness and othering demonstrates how moral transgressions concerning national identity justify aggressive verbal behavior against the offending party (e.g., accusations of drug use and mental ability insults). Collectively, the studies in Xie's (2018) special issue on impoliteness and moral order signal the multifunctionality of impoliteness-oriented utterances and the role that impoliteness as an analytical tool can play in examining and challenging individual and group identities. Questions regarding the exact nature of the link between impoliteness, morality and group identity remain, however.

\subsection{Impoliteness and intertextuality in Arabic discourse}

Research on impoliteness in Arabic contexts remains sparse and mostly disconnected from the retheorizations of impoliteness summarized in the previous section. For instance, a 2017 study by Hammod and Abdul-Rassul on impoliteness strategies in English and Arabic Facebook comments simply applies Culpeper's (1996) taxonomy of impoliteness to the selected examples (see also Mohammed and Abbas 2015) ${ }^{4}$. The remaining studies highlight the types of speech acts (e.g., agreement, compliment, apology, disagreement) used in various Arab countries (e.g., Iraq, Jordan, Saudi Arabia) to provide an understanding of Arabic communicative styles (e.g., Abdul Sattar et al. 2009; A1Adaileh 2011; Alaoui 2011; Al-Shlool 2016; Al-Zumor 2011; Ebadi and Salman 2015; Emery 2000; Farhat 2013; Feghali 1997; Mazid 2006; Najeeb et al. 2012; Nelson et al. 2002; Samarah 2015). An exception is Tetreault (2015), who examined the linguistic impoliteness-oriented practices of a group of second-generation Algerian immigrant teenagers in France: Following Locher and Watts (2005), the author adopted an expansive take on facework, theorizing it as more than mere mitigation of face attacks, to highlight the teens' use of Hashek, a North African politeness formula. The analysis demonstrated how the function of the Arabic formula is changed from showing deference in the North African discourse contexts to facilitating facework in multiparty contexts involving peers in France. Tetreault (p. 297) discusses impoliteness strategies "as part of larger reflexive processes in which meta-pragmatic strategies and language use come to encompass identity perception beyond the interaction". The author therefore argues

${ }^{3}$ Impoliteness as a tool to protect group identity through othering has also been demonstrated by Garcés-Conejos Blitvich (2010), Garcés-Conejos Blitvich et al. (2013), Kádár et al. (2013), Mak and Chui (2014) and Upadhyay (2010).

${ }^{4}$ Culpeper (2011) has revised this (1996) taxonomy. 
for a complex view of impoliteness research, especially as it relates to Arabs, given the centrality of face (i.e., the concept of le respect) in Arabic discourse.

Impoliteness, intertextuality and Arab identity in digital contexts has been the focus of a growing body of studies, including my own, that demonstrate the centrality of authoritative religious texts in negotiating Islamic identities on various digital platforms. In Al Zidjaly (2012), I analyzed posts that Arabs of differing backgrounds had left on the Al Jazeera news agency website in response to an article critiquing Arab cultural face. I examined this facework through the analytical lens of reasonable hostility (Tracy 2008), wherein expressing outrage is expected and encouraged in the democratic discourse endemic to social media (although Arabs were and remain new to this democratic/civic form of communication). Moreover, I referenced the Goffmanian (1967) concept of face (i.e., individuals' public image) to characterize the strategies Arabs used in the restorative stage (Ting-Toomey 2004) to maintain cultural face (i.e., the collective face of a nation [Ting-Toomey 1994]). The findings revealed the prevalence of selfface-attacks in response to the triggering article, which I associated with Arabic cultural practices of lamenting or self-flagellation (Hegland 1998; Wilce 2005) and getting the lower hand (Beeman 1986; Al Zidjaly 2006; 2015). I argued that by attacking their own face, Arabs put themselves at the mercy of more powerful agents, which paradoxically helps them gain the upper hand and exercise agency (through feeling bad for them which often leads to helping them out). Al Zidjaly (2010) demonstrated Arab Muslims' transformation of authoritative Islamic texts into internally persuasive ones that bring new understandings to old texts. In another study, Muslim Arab psychologists' referencing of Islamic authoritative texts in their consultations on an Islamic website was examined as a means of perpetuating Islamic texts in medical contexts (Al Zidjaly, 2017b). In Al Zidjaly (2019a) and (2020), intertextual religious references served the function of linguistically repairing Islamic ideologies to better align Islam with twenty first century tenets.

Building on Al Zidjaly (2010, 2012, 2017b) and Badarneh and Migdadi (2018), Badarneh (2019) further examined how intertextual references from Arabic religious and non-religious texts are used by a group of Arab elite intellectuals to perform acts of impoliteness in reader comments posted to a London-based pan-Arab news agency platform. The author (11) terms these types of posts as intertextual impoliteness, defined as "the use of a synchronic or diachronic intertextual reference whose content has conventionally become, in the Arabic sociocultural context, and from the point of view of society at large and its "ceremonial idiom" (Goffman 1967, 89), a "symbolic linguistic means for conveying impoliteness" (Culpeper 2010, 3232)". Badarneh's findings suggest that referencing religious and literary texts in this way positions the post author as intellectual and oppositional and the other as deserving of the putdown. Having established the role of authoritative texts in motivating acts of impoliteness, the implicit nature of impoliteness as used in the Arabic context is indicated ${ }^{5}$. This paper further explores the implicit use of this Arabic cultural practice of implicit impoliteness through intertextual references.

\footnotetext{
${ }^{5}$ See also Labben (2018) for more on impoliteness and Arab identity construction.
} 


\section{Data and analytical framework}

The data set is extracted from a larger longitudinal and ethnographic project on Arab identity and social media I commenced in 2015 (the impoliteness project is part of the section on the Arabic Reform Community [Al Zidjaly 2019a] ${ }^{6}$. Accordingly, I collected various types of data (e.g., over 50,000 tweets and memes with comments by Arabs from various religious and political backgrounds) to contextualize the use of impoliteness. I also collected larger discourses relevant to examining the role that impoliteness plays in the context of digital religious activism (e.g., the history of Islam, Islamic religious texts, cultural discourses, beliefs and daily practices).

In this paper, I zoom in on a thread of Twitter responses posted in reaction to a triggering comment that indirectly questions the morality of an established Islamic prayer, thus requesting its change (i.e., the questioned prayer or supplication limits requests of healing to Muslims). The triggering tweet generated 1500 comments; however, this paper includes only the first 300 comments, as these were posted within days of the original tweet and the remaining 1200 comments repeated strategies and sentiments demonstrated in the first 300, indicating the debate was resolved around the 300th comment. The set of comments selected for analysis represents what Herring (2004) refers to as sampling by theme (i.e., including the publicly accessible messages in a particular thread). The thread under analysis was selected because it represents the most liked, circulated, and commented-upon comments. I further include only first-order comments (those addressed to author) and exclude replies to comments (Culpeper 2006). Although I did not contact the tweet author or any commentators for feedback, I was already aware of the debate and sentiments involved, as I follow the tweet author and I too am a Muslim reformer.

Analytically, I draw upon Herring's (2004) computer-mediated discourse analysis and Bateman's (2014) multimodal approach to analyze the data. My examination further integrates recent theorizations of facework and impoliteness (discussed in the previous section) with the Bakhtinian concept of intertextuality (1981; Kristeva 1980), which asserts that texts and actions are in constant dialogue with past and future discourses. Specifically, I theorize impoliteness as an analytical lens to capture the impetus of moral shift in the Arabic context and intertextuality as crucial to a conceptualization of impoliteness as a culturally embedded practice (not just a local achievement). My analysis distinguishes two types of intertextual references: authoritative discourse, defined by Bakhtin (1981) as being from the past and closed to negotiation (e.g., the Quran, considered the word and instructions of God, and the hadiths, the reported sayings of the prophet of Islam documented in the authoritative books of Sahih Al-Bukhari and Sahih Al-Muslim); and internally persuasive discourse, which are open for discussion (e.g., praying for five or three times a day). I necessarily ground the aggravating tweet and its responses in these larger Islamic discourses, as the actions documented in this study are representative of various practices Arabs regularly use on social media platforms. Highlighting the role of intertextuality in negotiating Arabic moral order enabled

${ }^{6}$ The project, funded by Sultan Qaboos University in Oman, is entitled, The impact of social media on Omani youth: A multimodal project (SR/ARTS/ENGL/15/01) - 2015-2020. 
me to construct Twitter as a cultural tool (Scollon 2001) of change (in contrast to its traditional conceptualization as an affiliation medium (Zappavigna 2011). I, therefore, contribute to the sparse research on impoliteness on Twitter and identify a new function of impoliteness (i.e., creating a shift in consciousness), which extends well beyond its role as accentuation of group identity (Kádár et al. 2013) or resistance of moral order (Graham 2018).

\section{Analysis}

In this paper, I integrate moral and relational approaches to impoliteness. Impoliteness is defined herein as a mediated practice that is discursively and culturally embedded for the purpose of underscoring the "negotiability of the emic understandings of evaluative concepts such as polite, impolite, rude, etc., and, in connection with this, to highlight the embeddedness of the observed social practices within their local situated framework of the moral order (see, e.g., Kádár and Haugh 2013, p. 95)" (Locher 2015: 6). Moral order is defined in this paper as a ritualistic, authoritative practice engrained in the historical body (Nishida 1958) that requires cultural intersubjectivity for its change. The analysis section is divided into three parts: 1) the triggering tweet, 2) cultural contextualization to ground the tweet, and 3) the responses to the tweet (The rites of aggression); the response or comments section is in turn divided into three subsections: keeping the questioned supplication intact, responding to the first part, and changing the questioned practice.

\subsection{The triggering tweet}

The offending event (Jay 1992, 2000) or heckling (Kádár 2017a), as the majority constructed it, occurred on December 14, 2018. By February 10, 2019, when the data were collected, 1582 retweets, 5797 likes, and 1500 comments had been generated. Notwithstanding public condemnation, therefore, many did like the tweet. The author, animator and principal (Goffman 1967) of the tweet is a writer from the United Arab Emirates $^{7}$, as established by his profile with 89,800 followers. Judging by his tweets and his published novel, he is one of the Arab reformers engaged in propelling forward the social and religious revolution in Arabia (for details on the Arab Reform Community see Al Zidjaly 2019a). Unlike Ex-Muslims on Twitter, the author's tweeting style could be considered as moderately provocative because he refrains from questioning the Quran and the hadiths, the two most authoritative texts in Islam. Keywords for analysis are underlined in the translation.

(1) The triggering tweet and its translation

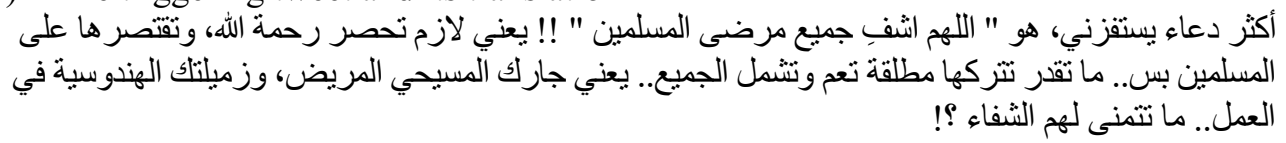

The supplication that provokes me the most is, "O Allah heal the Muslim sick"!!

\footnotetext{
${ }^{7}$ Given the sensitivity of the act, ethics and privacy concerns, I have not disclosed the author's name and account information.
} 
So, the mercy of Allah must be delimited and restricted to Muslims only.. Can't you simply leave it general to include everyone.. That is, your Christian neighbour who [happens to be] ill, and your Hindu co-worker.. You don't wish good health to them ?!

1,582 Retweets 5,797 Likes

This tweet, which consists of two parts, is triggering in three primary ways. First, by declaring an opinion that the widely practiced prayer is provocative (e.g., The supplication that provokes me the most $)^{8}$, the author uses direct expressed agitation to resist and indirectly construct as immoral an established Islamic moral order (i.e., to pray for the salvation of Muslims only). Second, the author issues a face-attack wherein he calls out Muslims on their exclusive acts (thereby indirectly constructing Muslims as racists by questioning the lack of humanity involved in limiting God's love to one kind [Muslims] while excluding others [Christians and Hindus, the two major non-Muslim identities found in the Islamic Arabian Gulf] $)^{9}$. In total, by inviting debate, the tweet poses an indirect request (directive) that Arabs turn an authoritative practice into an internally persuasive one. Third, the triggering tweet features a code switch between two dialects of Arabic: The first part (e.g., The supplication that provokes me the most) and the prayer itself (i.e., O Allah heal the Muslim sick) are in classical Arabic, constructing the expressed agitation as formal and the prayer as an authoritative text. The insult or face-attack (e.g., So, the mercy of Allah must be delimited and restricted to Muslims only ... You don't wish good health to them?!) is written in colloquial Emirati dialect, constructing it as informal. This intentional code switch between formal and colloquial Arabic, termed heteroglossia with awareness (Bakhtin 1981; Tovares 2019), makes the attack personal.

The intended audience of the face-attack is the Arabian Gulf people, given the location and nationality of the author of the tweet and his use of the Arabian Gulf dialect, making the online context less collapsed (Georgakopoulou 2017), rendering it a little easier to identify the persons involved in the negotiation of an Islamic moral order. The tweet, however, does reach Arab Christians from Egypt who join to correct misconceptions about their Christian prayer practices ${ }^{10}$.

\subsection{Cultural contextualization}

Bousfield (2007: 2188) explained, "impoliteness is only that which is defined as such by individuals negotiating with the hypothesized norms of the Community of Practice". Therefore, what one culture might consider polite might be "sanctioned aggressive facework" (Watts 2003: 260) or heckling (Kádár 2017a) in another. Thus, the cultural context merits consideration when reviewing the triggering tweet to understand how Arabs appraise and respond to such acts.

${ }^{8}$ The prayer in question is representative of a long list of inclusive Islamic rituals that bestow healing and blessings solely upon Muslims.

9 Although Islam is a religion, not a race, the indirect illocutionary force of the tweet constructs non-Muslims as a different race and Muslims as an imagined race. This is a common mixing of terms in Arabic discourse.

10 The Islamic world consists of 50 Muslim countries (but only 23 of them identify as Arabic countries). Out of the 23, 6 identify as Arabian Gulf countries; these include: Oman, Qatar, Bahrain, Kuwait, The Kingdom of Saudi Arabia and the United Arab Emirates. 
First, one reason that many constructed the triggering act as offensive is because it was meant to disrupt Islamic intersubjectivity, defined as a display of mutual understanding of both conversational activities at hand and larger cultural norms that govern such conversations and actions (Schegloff 2007) — what Kádár (2017b) names as moral order or situated norms (Graham 2018). This construction is in line with the kinds of tweets that the author often posts. The action (and its indirect request to change the prayer) is also part of a larger reflexivity action that Arabs have been engaged in since the introduction of Yahoo chatrooms (Al Zidjaly, 2019a, 2020). The main purpose of this movement is to disrupt assumed norms or intersubjectivity to create a new Muslim identity which is more accepting of difference by repairing (or changing) Islamic authoritative texts (the Quran and hadiths), constructed by the reform community as problematic texts (Al Zidjaly 2020). This paper provides a representative example of another strategy to create reform by requesting the change of Islamic practices that are neither Quran nor hadith. Because these practices are not authoritative (i.e., not from Quran or hadith), change is often carried out by known members of the society (as questioning them does not result in incarceration). Both groups are part of a movement on Twitter and YouTube to create a more humanitarian Islam that cares about people of all background first and Muslim identity second. This is the motto and goal of the Arab Reform Project. This contextual information is necessary to keep in mind because, in many instances, what provoked commentators about the triggering tweet's request to pray for all instead of for Muslims only is that it is part of an ongoing attack on Muslim identity and request to reform Islamic texts and practices from outsiders (e.g., non-Muslim governments) and insiders (e.g., Muslims) alike. This request to shift practices pertains to identities and loyalties, and an indirect construction of Muslims as racists towards non-Muslims (a charge made directly in other contexts) explains their construction of this tweet as a face-threatening, aggressive act aimed to disrupt. Therefore, in many of the responses, commentators are addressing both the implied request to, locally, change the verbal text of the prayer from "heal Muslims" to "heal all", and, globally, engage in larger acts of critiquing and reforming Islam. While many of these acts are carried out by ex-Muslims or outsiders, the triggering tweet was especially face-threatening because it was an insider attack.

Second, Islamic identity is based on religion (Lewis 2001) and Islam is engrained in daily activities. In other words, religion is not just a part of Islamic identity, it is the identity. Any attack on a practice is therefore an attack on Muslims themselves. Because religion is the source of their identity, verses from the Quran and hadith as well as ritualistic prayers are memorized by all since childhood - it is a rite of passage into adulthood. Therefore, many intertextual references in this study are only implied ("this is what we have learnt", Example 2) because they are part of the Islamic historical body (Nishida 1958). Furthermore, because Muslim identity is based on religion, any act by Muslims has to be justified through religious texts. For instance, Badarneh (2019) illustrated how Muslim Arab intellectuals' reference authoritative texts from the Quran, the hadiths and even poetry to justify impolite verbal attacks on others. Because any form 
of action has to be sanctioned by religious texts, intertextual references are therefore key to the reform project.

Third, I opted for the terms divine politeness and divine impoliteness versus devout (im)politeness because by referencing divinely inspired authoritative texts that include impolite, hostile or exclusionary verbal attacks against non-Muslims, it follows that a devout Muslim must be impolite as outlined in the texts. In this scenario, it is not the Muslims who are being impolite, but rather God or the Almighty Himself. Muslims are simply following the divine texts. However, as it becomes clear in this analysis, the questioned prayer actually was not a hadith and the request to change it was taken up. Notably, when the triggering tweet's author took a follow-up poll five months after the original tweet, $89 \%$ (of 3600 votes) agreed to changing the prayer. Relative to the Arabic cultural context, I therefore introduce the term divine impoliteness that is, similar to indirect ritual offence (Kádár 2017b) and authorized transgression (Vásquez 2016), a linguistic strategy, position, speech act, or utterance that easily can be constructed as face-threatening, but which is legitimized by hostile religious texts or cultural practices ${ }^{11}$.

\subsection{The rites of aggression}

Kádár (2017a) proposes that the rites of moral aggression comprise a natural process to defend what has been attacked. However, unlike typical defensive counterattacks against national or cultural face, the rites enacted in this example unexpectedly take a positive turn, with a proportionate number of Arabs siding with the instigator in favor of changing the questioned Islamic moral order. This is unexpected given the religious nature of Muslim identity and community (Al Zidjaly 2017b), which explains why the majority defended in favor of keeping the moral order intact.

I have organized the analysis of these rites of moral aggression into three sections: 1) comments in favor of maintaining Islamic norms or moral order (justified through divine impoliteness); 2) positive and negative reactions to the expressed divine impoliteness, which reference religious texts that are aggressive towards non-Muslims; and 3) comments supportive of shifts in the norms and moral order (justified by divine politeness or religious texts that are not aggressive towards non-Muslims). Within the three categories, I identify ten strategies commentators used to enact the rites of moral aggression, which alternately employed and rejected divine impoliteness. Each strategy consists of various sub-strategies that concomitantly occurred (e.g., projecting Islamic practices onto other groups, author attacks). Questioning was a key strategy used across the categories to query the norms and their authoritativeness in service of advancing the negotiation rather than halting it by claiming its authoritativeness. Accordingly, the discussion proceeds from non-negotiability to openness.

11 To that end, while much digital interaction has been increasingly characterized as impolite (Graham and Hardaker 2017; Graham and Dutt 2019), troll-like (Tovares 2019) or a "fertile ground for conflict" (Hardaker 2015, p. 201), I argue in this paper (as I did in Al Zidjaly 2012) that a reasonable amount of hostility (Tracy 2008) on Twitter is expected and encouraged, given its use as a form of civil engagement. 


\subsubsection{Divine impoliteness: Those opposed, say no}

The triggering author's use of the word provoke (meaning in Arabic to anger or bother), construction of Muslims as racists and consequent threat to Arabs' positive face (Brown and Levinson 1987) and request to change an authoritative (Bakhtin 1981) Islamic practice stirred many negative emotions in commentators, evidenced by their impolite-oriented responding tweets of moral indignation and judgment (Culpeper 2011). Most of these commentators perceived the tweet as a public face-attack on Islamic Arabic identity and felt socially pressured to justify the questioned cultural practice.

Many of the immediate reactions to the original tweet reject its inference of immorality by constructing the prayer as a marker of group identity rather than an insult to people from other cultures. Commentators also express the view that everyone else (e.g., Christians and Hindus) does this same act, thus projecting Islamic beliefs and practices onto others. In Example 2, chosen as representative of a larger set, divine impoliteness is referenced indirectly through stating (This is what we have learnt) and that there are (divine rewards) in doing what we have learnt, indexing the authoritative nature and the normalization of Islamic exclusive practices learnt long ago in childhood.

(2)

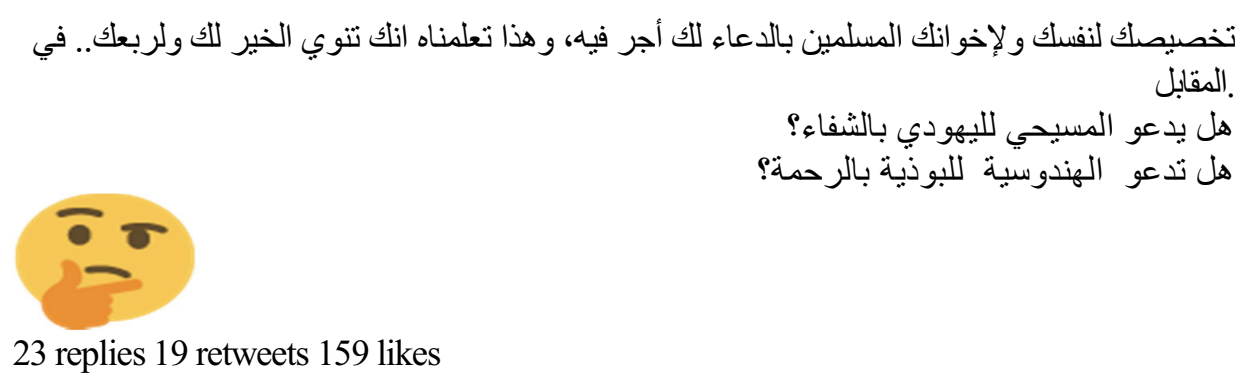

\section{Translation}

Your restricting the supplication to yourself and your Muslim brethren, there is reward in it. We have learnt that it shows that you wish the best for yourself and your people. In contrast,

Do Christians pray for the good health of Jews?

Do Hindus pray for mercy for Buddhists?

Example 2 demonstrates interplay between visual and verbal components (Bateman 2014) to discredit the triggering tweet's indirect moral judgment of Muslims to change what commentators consider a perfectly well-established and normal cultural act. The perplexed emoji visually signals the absurdity of the request, while the comment verbally justifies the existing practice in three main ways. First, exclusiveness is constructed as a virtuous collective feature of Muslim identity through pronouns such as we, yourself, your Muslim brethren, your people as in "Your restricting the supplication to yourself and your Muslim brethren", stating "it shows that you wish the best for yourself and your people", and noting that, in the Quran and hadiths, God says he rewards those who highlight their Muslim identity (e.g., "there is reward in it"). Second, stating that "We have learnt", without sourcing the original texts, additionally highlights the authoritative nature of such acts. In other words, the us-and-them stance created by the prayer 
and defended in Example 2 construct exclusiveness as a positive expression of the group identity key to Arabic cultures based on tribalism (Hofstede 1990), rather than a politeness concern.

The commentator's divisive stance is further enhanced by contrasting Muslim behavior with the prayer behavior of others through a set of questions aimed at inviting others to align with the position of the commentator. This whataboutism strategy attempts to justify Muslim behavior through questioning: Do Christians pray for the good health of (their projected nemesis) Jews? Do Hindus pray for mercy for (their projected nemesis) Buddhists? These unsubstantiated examples project both cultural practices and imagined nemeses onto the other, all in defense of the existing norms or religious practices based on cultural texts (i.e., everyone else does it so why should we stop or be criticized for it). This normalization of behavior strategy to save threatened collective face receives many likes, retweets and responses, as indicated in Example 4 (below). According to Tovares (2006), while many rhetorical questions do not receive answers, the ones posed in Example 2 do receive answers from Egyptian Christians — but only after commentators move from projecting their practices onto others into attacking Christians and Hindus for doing worse than simply not praying for others, as Example 3 indicates.

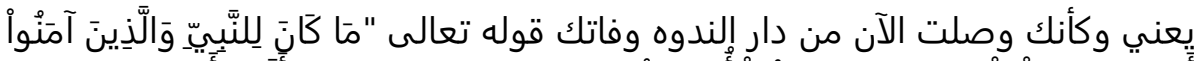

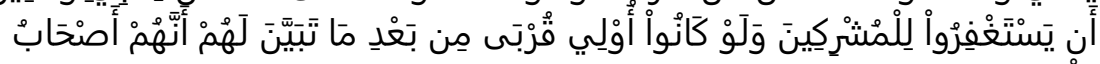

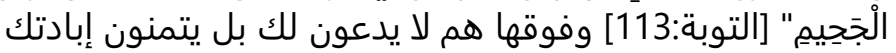

So, it looks as if you are just now arriving from the pre-Islamic era, and you have missed hearing the saying of the Almighty:

"It is not for the Prophet and those who believe to pray for the forgiveness of the idolaters - though they be close kin — after it becomes clear to them that they are destined for hell" [Quran 9: 113].

Over and above that, they don't pray for you; rather, they hope for your extermination.

Example 3 concomitantly draws upon three types of impolite responses to reject the request put forth by the original tweet: The first part mocks the author by constructing him as a pseudo-intellectual who apparently does not know that things have changed since Islam was introduced (e.g., "it looks as if you are just now arriving from the preIslamic era"). Part two indicates that divine texts exist that prohibit Muslims from praying for non-Muslims - even if kin — because God the Almighty has decided they are destined for hell for not believing in him. This direct example of divine impoliteness justifies an aggressive cultural behavior of exclusion (choosing Muslim identity over humanity) based on a text from the Quran that bans Muslims from asking for forgiveness to non-Muslims. The logic is: because we have such divine texts that forbid us from praying for non-Muslims, we have no choice but to abide by the almighty, as he wants us to be impolite to others. Part three goes one step further by directly accusing Christians and Hindus of wishing bad will to Muslims (e.g., "Rather, they hope for your extermination"). In this accusation, the pronoun your is used in place of the group marker our, constructing the author of the triggering tweet as disaligned with both the Muslims and the non-Muslims he defends. 
Projecting one's behavior onto others (that others do it too) fails as a productive strategy when Egyptian Christians defend themselves (see Example 4) by challenging the questions and correcting the fallacious accusations made by Muslim commentators in Examples 2 and 3.

(4)

$$
\begin{aligned}
& \text { عزيزى المحترم ا. احمد تعليقى على حضرتلك يخص اخر سطر فقط مين فال انتا مش بندعى لحضى لحضرتلك مين }
\end{aligned}
$$

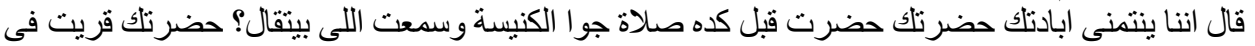

$$
\begin{aligned}
& \text { الانجيل وشوفت عدد الايات اللى بتطلب من الانسان انه يحب عدوه عدوه و المسئ إليه؟ }
\end{aligned}
$$

My dear, honoured Mr. Ahmad, my comment to you concerns the last line only: Who says that we are not praying for you? Who says that we wish your extermination? Have you prayed before in Church and heard what was said? Have you read in the Gospels and seen the number of verses that command that mankind love his enemies and those who offend [against] him?

The response in Example 4, written in Egyptian dialect, draws upon two linguistic strategies to highlight respect: 1) Egyptian polite discourse markers (e.g., addressing the attacker with honored Mr. and the Egyptian formal address term Hadretuk [akin to Vous in French]) and 2) formal letter writing rather than spoken style (with direct address and name). To counter the projections and accusations, the author of the response poses questions aimed to discredit the source of the accusation, linguistically mirroring the style of Example 2 (e.g., what evidence do attackers have to claim knowledge of the content of Christians' prayers in churches or that Christians wish ill for Muslims?). To demonstrate the contrary, the commentator answers his own questions by reminding tweeters of the Bible's instructions to love their enemies and those who attack innocent people. By using conventionally polite discourse markers (Schiffrin 1989) and indicating the Bible's stance on love for all humans, the Egyptian commentator demonstrates the divine source of Christian politeness. Other Christian Egyptian commentators engage in the discussion, signaling the wide reach of the tweet.

Once projection fails, the majority of Muslim Arab commentators give up on rhetorical questions as a productive strategy and select a new strategy of divine impoliteness: directly drawing upon the two most authoritative texts (Bakhtin 1981) in Islam (the Quran and the hadiths) to sanction the impolite ritualistic prayer. Also, in contrast to Example 3, which referenced the divine text in conjunction with other linguistic strategies (e.g., ridiculing the author, verbally accusing others), Example 5 indicates an unapologetic stance against change, as the divine texts that index an aggressive behavior towards the other are listed as stand-alone.

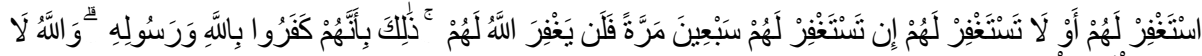

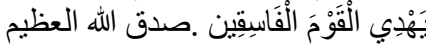

A. [A quotation from the Quran 9: 80] (Whether you ask for their forgiveness or not. If you ask for their forgiveness seventy times, Allah will not forgive them. That is for their rejecting Allah and His messenger. Allah does not guide an immoral people). God is the truth speaker. 


$$
\text { النبي استأذن الله ان يستخفر لأمه فلم يأذن له ، فبعدها استأذنه ان يزور قبر ها فأذن له }
$$

\section{B. A redacted Hadith:}

The Prophet asked leave of Allah to request forgiveness for his mother, but it was not granted him. After that, he asked leave to visit her grave, and it was granted.

Example 5A draws upon a verse from the Quran that disqualifies prayers of forgiveness (of any length) for non-Muslims as punishment for not believing in him. Consequently and indirectly, the commentator argues that praying for non-Muslims is futile and should not be done. The authoritativeness of the text (its unquestioned status) is signaled by the use of vocalization, a Quranic linguistic strategy, and the end statement of (God is the truth speaker), verbalized after reciting Quranic texts. Example 5B, posted by a different person, strengthens the argument for preserving the questioned practice by intertextually referencing the second most authoritative text in Islam to justify divine exclusiveness, as the story (extracted from a known hadith) indicates the prophet of Islam was allowed to visit the grave of his non-Muslim mother, but was forbidden by God to pray for her salvation ${ }^{12}$, thus demonstrating the exclusion of non-Muslims from God's mercy. Together, the intertextual references to authoritative Islamic texts legitimize verbal impoliteness against non-Muslims and present examples of divine impoliteness (impoliteness sanctioned by religious texts) ${ }^{13}$.

Divine impoliteness creates a moral dilemma among the responders and bystanders. To exonerate themselves from the implicit charge of impoliteness (and the entailing racism against the other), the tweeters discuss the moral responsibilities of Muslims towards non-Muslims in accordance with the general Islamic moral order. A negotiation of the Islamic moral order (i.e., Islamic norms and cultural practices) ensues.

(6)

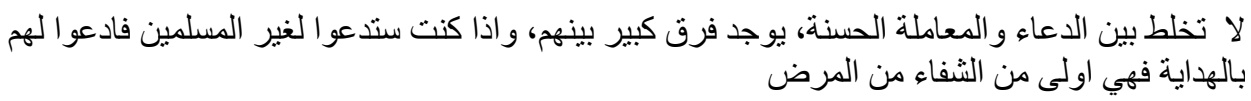

A. Do not confuse supplication with good deeds; there is a big difference between the two. If you pray for non-Muslims, pray for their guidance, for that takes priority over healing from disease.

$$
\text { لا يجوز لنا الدعاء لهم إلا بالهداية إلى الدين الحق }
$$

B. We are not permitted to pray for them except for guidance to the true religion

In Example 6A, a commentator cautions against confusing Islamic prayers (i.e., rituals to accentuate group identity) with polite behavior, indicating they do not see how not praying for others is an impolite verbal act. The commentator instructs: If Muslims have to pray for non-Muslims, prayers for the salvation of their souls should trump

12 An interesting note about this hadith is that the prophet's mother died when he was just a child of approximately 7 years old, meaning his mother died before Islam was created (Mohammed became prophet at age 42).

${ }_{13}$ Note that the source of both texts is not provided, signaling the ubiquity of the texts. The Quranic verse ends with trust God as he is the speaker of truth, the known ending phrase of Quranic verses. 
prayers for the salvation of their bodies. This moral stance is condoned in Example 6B by a different poster, who declares, based on known but uncited Islamic teachings, that Muslims' only (verbal) moral obligation toward others is to pray for their guidance towards Islam, as anything else is forbidden. This declaration is prefaced with the plural pronoun we, highlighting group identity and the us-versus-them moral stance created from the onset of the rites to correct the perceived moral aggression of the triggering tweet.

\subsubsection{Reaction to divine impoliteness}

The divine impoliteness of prohibiting others to pray for all people angers many, leading to ridicule and accusations of racism in both directions. Those in favor of changing the prayer verbally align with the triggering tweet's author and attack those who want to preserve the impolite ritualistic prayer. The following are some of the most-liked tweets in support of changing Islamic prayers to include good will for all humans. The tweets also oppose all who justify racism (in prayers) against the other through referencing divine texts.

(7)

\begin{tabular}{|c|c|}
\hline A. I agree with you & اتفق معك \\
\hline B. Bravo! You have opened my eyes & بر افو ! فتحت عيني \\
\hline C. Bigotry at its finest & العنصرية فى اقصى صور ها \\
\hline $\begin{array}{l}\text { D. Paradise, mercy, and other such, is } \\
\text { a privilege reserved for some }\end{array}$ & الجنة و الرحمة وغير ها أمتياز حصري للبعض \\
\hline $\begin{array}{l}\text { E. You are right: May Allah grant health } \\
\text { to everyone ill }\end{array}$ & ق اللهم اشف كل مر \\
\hline
\end{tabular}

Example 7B demonstrates support for the tweet that opened commentators' eyes to new possibilities. This admission is significant, as is the original triggering text, as such discussions of Islamic moral order are frowned upon (in some cases, forbidden); it is only the fact that the prayer was proven not to be a hadith (and also the choice of anonymity of social media) that have created a platform for such exchanges. Their assent is accentuated with sarcastic remarks against those favoring maintenance of the moral order, claiming it exposes them as racist (7C) and reflects distorted thinking regarding salvation (7D). Subsequent tweets repair the ritualistic behavior, replacing it with inclusive prayers for all to heal (Example $7 \mathrm{E})^{14}$.

To retaliate against the support shown for the triggering act and the rejection of divine impoliteness, those in favor of preserving the Islamic prayer enact five types of actions: attacking the tweet author, ridiculing him, questioning his identity as Muslim, provoking him and the supporters by repeating the questioned prayer, and defining Muslim identity. Example 8A, for instance, attacks the author's character by portraying him as a pseudo-intellectual. They ask God to heal him, which is a sarcastic statement uttered in the Arabic context to those who are mentally disturbed. In Example 8B, the commentator questions whether the author really is Muslim (being ex-Muslim is a crime that may lead to incarceration in Islamic societies).

14 To learn more about Arabs' repair actions of Islamic authoritative texts, see Al Zidjaly (2019a, 2020). 
(8)

\begin{tabular}{|c|c|c|}
\hline $\begin{array}{l}\text { A. Author- } \\
\text { ridicule }\end{array}$ & $\begin{array}{l}\text { By Allah, right! } \\
\text { Blah blah blah } \\
\text { The fellow [lit. brother] is } \\
\text { an ignoramus } \\
\text { Egalitarian, cultured [or educat- } \\
\text { ed], and forgiving but heedless } \\
\text { God heal you }\end{array}$ & 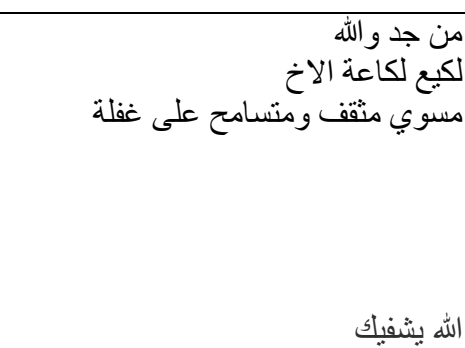 \\
\hline $\begin{array}{l}\text { B. Author- } \\
\text { identity attack }\end{array}$ & $\begin{array}{l}\text { On the Day of Resurrection, } \\
\text { the prophet Muhammad (May } \\
\text { Allah grant him peace) will } \\
\text { call upon his nation. Will that } \\
\text { provoke you too??? }\end{array}$ & 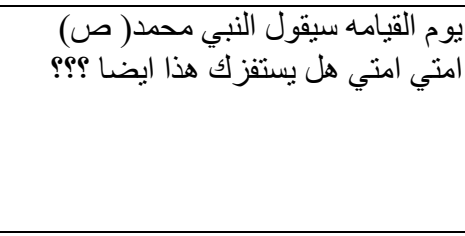 \\
\hline C. Provocation & $\begin{array}{l}\text { May Allah heal all Muslims } \\
\text { who are ill. Only. Does that } \\
\text { ease your mind, Sir? Provoked? } \\
\text { Go to hell, Sir }\end{array}$ & ارتحت يأسيدي انترفزت مرضى المسلمين بسيد. \\
\hline $\begin{array}{l}\text { D. Muslim } \\
\text { identity }\end{array}$ & $\begin{array}{l}\text { We as Muslims are tolerant; } \\
\text { we wish the best for our kind } \\
\text { and we hope the same for others } \\
\text { out of humanity, no dispute } \\
\text { about that. Specifying suppli- } \\
\text { cation for Muslims "ought not } \\
\text { to be provoking". Rather it is } \\
\text { a natural matter; we hear it } \\
\text { in the Friday sermon and we } \\
\text { say "Amen" }\end{array}$ & 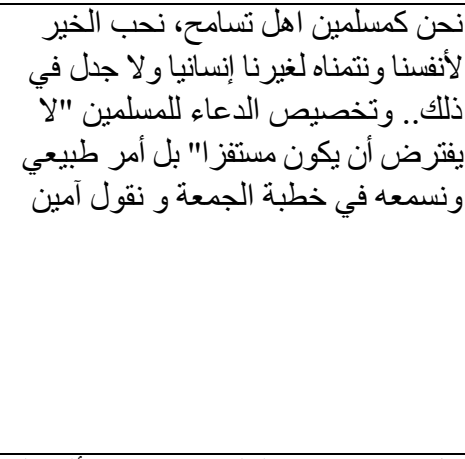 \\
\hline $\begin{array}{l}\text { E. Questioning } \\
\text { Author }\end{array}$ & $\begin{array}{l}\text { Have you studied this piece of } \\
\text { knowledge and found that the } \\
\text { diction is legally legitimate, or } \\
\text { are you making it up without } \\
\text { knowledge, thereby becoming } \\
\text { one of those who makes up } \\
\text { unseemly regulations for Islam? } \\
\text { There will be a price to be paid } \\
\text { for that on the Day of Resur- } \\
\text { rection. Allah did not permit } \\
\text { the prophet, may Allah grant } \\
\text { him peace, to pray for the for- } \\
\text { giveness of his mother when } \\
\text { she died as an idolater; and the } \\
\text { prophet did not pray for the } \\
\text { health of his Jewish neighbor, } \\
\text { but he did visit him and invited } \\
\text { him to [embrace] Islam. }\end{array}$ & 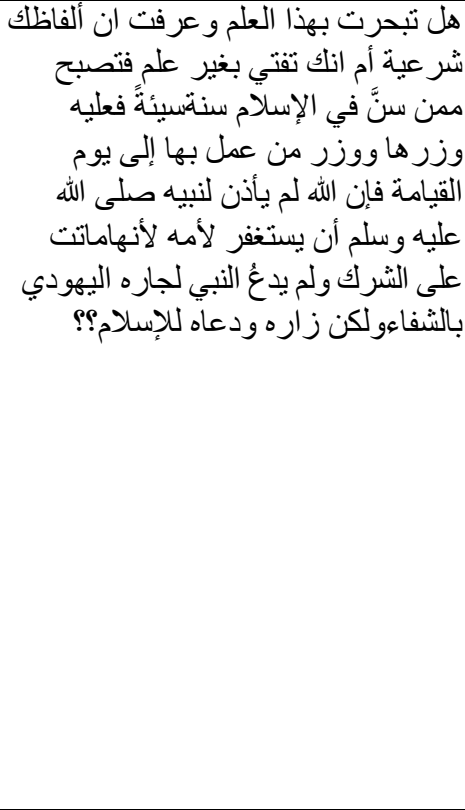 \\
\hline
\end{tabular}


By asking the author if he would be bothered in the afterlife when the prophet of Islam calls out for his nation on Judgment Day, Example 8B further claims that group identity (including the belief in exclusiveness) is central to Islamic identity. Accordingly, this example questions the author's loyalty to Islam and Islamic identity. Example 8D also defends exclusiveness, simultaneously and directly stating that exclusiveness is a natural (rather than sinful) trait, and an outcome of love for oneself first. Example $8 \mathrm{C}$ seeks to accentuate the prayer's provocation and Islamic exclusiveness by adding the modifier only (God heal all Muslims who are ill. Only). The author is then bullied through a direct, ironic inquiry about his attitude before the commentator signs off with go to hell, sir, indicating rudeness and lack of care. Example 8E questions the author's authority and the legitimacy of his triggering question, indicating that in Islam any form of social change must be sanctioned by religion, whether by God as in past examples, or by religious men as in this example. Putting forth the need to sanction behavior by religious texts or men alerts those supportive of change to mirror the linguistic strategies their counterparts deploy to shift consciousness.

When emotions run high and the legitimacy of requesting the moral shift is questioned, those supportive of change realize the necessity of referencing divine sources if they are to succeed. They additionally realize the resourcefulness of questioning (as per their counterparts) as a linguistic strategy to bring about change.

(9)

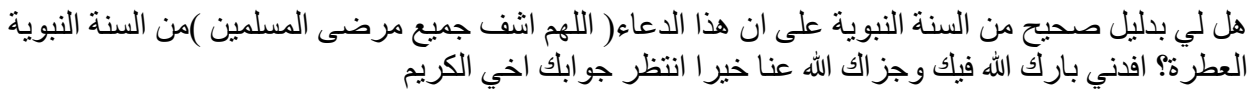

Is there reliable evidence from Sunna (hadiths) that proves that this supplication (God heal all Muslim patients) is from the reputable prophetic tradition? May Allah bless you, Sir, and may Allah reward you with good from us. I await your answer, my good brother.

In Example 9, a commentator turns the table on the divine impoliteness group by asking whether the questioned prayer is a hadith (an authoritative text)? If so, it shall remain unchanged, but if it is simply a historic prayer, then change is possible. This question shifts the balance and exposes the resistance to change endemic to Islamic societies.

Despite a lack of supporting evidence, many Islamic texts and practices are treated as authoritative (sanctioned by God and his prophet). The prayer is found to not be a hadith. Recognizing that the questioned prayer was not an authoritative text (i.e., neither a Quranic verse nor a hadith) helped advance the discourse of shifting the Islamic moral order, motivating others to pose more questions and proceed with humanitarianinspired change that questions the Islamic moral order oriented around exclusiveness.

\subsubsection{Divine politeness: Those in favor, say aye}

The examples in this section present many questions and answers that move the discussion of the Islamic moral order from being nonnegotiable (authoritative) to one being internally persuasive, capable of being discussed and reconciled with humanitarian tenets and love for all. 
(10)

\begin{tabular}{|c|c|}
\hline $\begin{array}{l}\text { A. Why do you forbid praying for the } \\
\text { health of all innocents while you } \\
\text { call them to Islam? }\end{array}$ & للماذا تمنعون الدعاء بإنهاء بالثفاء للمرضى الأبرياء بينما \\
\hline $\begin{array}{l}\text { B. Religion is humanitarian before all } \\
\text { else }\end{array}$ & الدين إنسانية قبل كل شيء \\
\hline $\begin{array}{l}\text { C. Yes, our Islamic religion is mercy } \\
\text { to the worlds }\end{array}$ & نعم ديننا الإسلامي رحمة للعالمين \\
\hline $\begin{array}{l}\text { D. This civilized tolerance will take } \\
\text { us to the top and it is not farfetch- } \\
\text { ed [that] it will bring us to the core } \\
\text { of religion and the guidance of the } \\
\text { Messenger when he visited his } \\
\text { Jewish sick neighbour. }\end{array}$ & 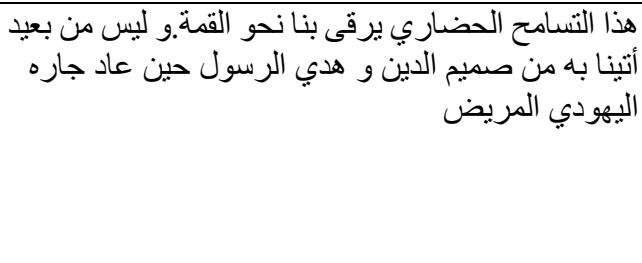 \\
\hline
\end{tabular}

Example 10B redefines religion as humanitarian. Example 10A questions the morality of praying only for others' conversion to Islam while neglecting to pray for their healing. Example 10C immediately justifies $10 \mathrm{~A}$ by referencing religious texts to justify inclusion that Islam (per the Quran) is sent for mercy to all universes, not just Muslims or this universe. 10D draws upon a hadith where the prophet visited his sick Jewish neighbor, indicating the inclusiveness of merciful acts and supporting the strategy of divine politeness. These various examples, by using authoritative texts to demonstrate that forgiveness and inclusion are actually part of Islamic religion, represent a strategy of divine politeness.

Once an increasing number of people agree that the religion of Islam does not reject humanitarian actions, questions about the form of a new, more inclusive, humanitarian, and merciful moral order are posed, leading some to extend healing to all living creatures, not just humans.

\begin{tabular}{|c|c|}
\hline $\begin{array}{l}\text { A. The reward in praying for their } \\
\text { health has been made clear to me, } \\
\text { and praise be to Allah for the grace } \\
\text { of Islam. Thank you }\end{array}$ & 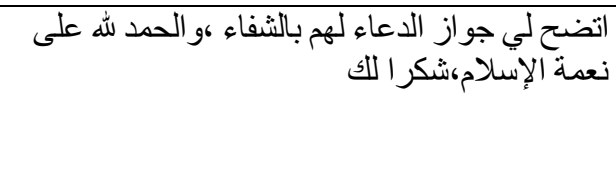 \\
\hline $\begin{array}{l}\text { B. To pray for the health of unbeliev- } \\
\text { ers who are not at war [with us] is } \\
\text { good and moral, but what would you } \\
\text { want the style of prayer to be? }\end{array}$ & 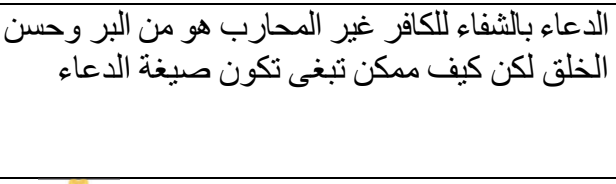 \\
\hline $\begin{array}{l}\text { C. When I pray, I say, "O Allah heal } \\
\text { your whole creation" }\end{array}$ & 12 \\
\hline $\begin{array}{l}\text { D. We wish health of all those who are } \\
\text { ill, Jinn and mankind }\end{array}$ & نتمنى الثفاء لجميع \\
\hline
\end{tabular}

Together, this analysis illustrates the workings of (im)politeness and Islamic intersubjectivity concerning Islamic moral order: Namely, how the instigator used impoliteness as a linguistic strategy to disrupt Islamic intersubjectivity, how some 
commentators used impoliteness to maintain intersubjectivity by referencing religious texts that sanction exclusion, and how other commentators used politeness to disrupt and shift intersubjectivity by referencing texts that encourage inclusion.

\section{Discussion and Conclusion}

In this paper, I used impoliteness as an analytical lens to capture the shift in the Islamic moral order as manifested on Arabic Twitter. The analysis specifically identified ten strategies commentators used to enact the rites of moral aggression and alternately employ and reject divine impoliteness in response to a triggering cultural attack: discrediting the moral judgment, projecting onto other cultural groups, responding to the projection, referencing authoritative texts, considering Islamic moral responsibilities toward others, attacking the existing Islamic moral order, launching ridicule and counterattacks against the triggering author, turning to religious clarification, proposing legitimate negotiation of the Islamic moral order, and initiating the start of an actual shift in the moral order. This examination of impoliteness was useful for understanding what Arabs do in digital contexts and why such actions matter, thus aiding in capturing one historic digital moment (of many) made possible by the agency of Arabs on Twitter.

Although present sociolinguistic research suggests that attacked individuals appropriate impoliteness to enhance group identity (Georgakopoulou and Vasilaki 2018) or to resist a particular moral order (Graham 2018), this paper demonstrated that, through the rites of moral aggression, impoliteness-oriented discourse served to create and maintain alliances (Graham 2007, 2008), help negotiate personal relations (Locher 2018), and ignite a reshaping of cultural identities. Specifically, commentators shifted from using divine impoliteness to justify a questioned moral order to appropriating divine politeness to justify the change in Islamic moral order and reconcile them with humanitarian principles. Accordingly, this study demonstrates that impoliteness is not only a relational concern at the linguistic level, but a cultural concern at the social level - key to disrupting an old intersubjectivity and erupting a new intersubjectivity. In their efforts to create this new intersubjectivity, Arabs are not just repairing problematic religious texts (as I demonstrate in Al Zidjaly [2020]), they also are highlighting the non-aggressive, the non-impolite texts as a source to create a new moral order. These findings foreground the call made by Kádár (2017a) to examine the workings of impoliteness and moral order in under-studied non-Western cultures. Doing so is needed to properly theorize impoliteness-oriented discourse because as a cultural tool, its functions are deemed to vary. Impoliteness therefore merits continued examination in digital contexts, as social media platforms provide heretofore unprecedented access to different types of data, cultures and actions (KhosraviNik 2016; Al Zidjaly 2019b). According to Blommaert (2018), social media moreover provide the opportunity to test and fully theorise terms and concepts - in this case, allowing me to linguistically identify a new function of impoliteness that goes beyond relational work to cultural work with larger, yet to be realised effects.

Linguistically analyzing Arabs' Twitter-based negotiation process following cultural attack also revealed the role that religion can play as a resource for impoliteness, rituals and the moral order (while highlighting the role that intertextuality, questions 
and pronouns can play in the negotiation process). The centrality of religion to Arab identity suggests that the key to advancing Arab reform might lie in intertextually referencing inclusive religious teachings and texts needed to sanction the reconciliation of Islam with so it reads the tenets of the 21 st century - shifts that are key in an increasingly digitized and globalized world. Although this might be irksome for Ex-Muslim reformers, this route may offer the most expedient path to change, given the religiously engrained nature of Arabic societies (Lewis 2001). Further, as this analysis indicated, Islamic authoritative texts allow for various interpretations and even anecdotes of actions and Islamic practices assumed to be authoritative may actually be malleable cultural practices (see Example 9), underscoring the importance of ongoing examination of such texts. Impoliteness as a cultural practice connected to moral orders of societies therefore was shown to be a driving force of the Arabic reform project, as it was the negative reactions produced by divine impoliteness that prompted an attitude shift. Impoliteness also was central to unraveling and to understanding social change. This bears further examination in different cultural contexts and social media platforms to adequately theorize the links between impoliteness, moral order and social change.

In sum, this paper contributes to advancing the Arabic reform movement I documented in Al Zidjaly (2019a). The analysis not only contributes to impoliteness and social media research, but also to research on Arab identity and sociolinguistic theory and method. Impoliteness-oriented discourse, as a key to cultural revolution, is an important tool in the process of cultural reflexivity occurring in digital discourses among Arabs. Giddens (1990) noted that such reflexivity is a main ingredient in the creation of democratic societies. Being able to witness the negotiation has made it easier to fathom what goes into the making of Arab identity and analyzing the workings of such cultural reflection has provided a rare glimpse into the shifts needed for Arabs to integrate into an increasingly globalized, connected world. This is a notable counterpoint to the cynicism typically surrounding social media actions and actual change (See Mozorov 2011 for a discussion). The ramifications and extent of such changes in Islamic society are yet to be measured; in the meantime, divine politeness appears to have ignited change among the participating Arab commentators. My ongoing ethnographic documentation of Arabs' digital actions demonstrate that since the represented tweet and ensuing discussions, inclusive Islamic prayers frequently appear on Twitter and WhatsApp. They signal an actual shift in the Islamic identity which is historically centered around exclusiveness. Twitter therefore has played a key role in providing Arabs with a platform to engage in cultural reflexivity, and impoliteness has provided Arabs the linguistic tool to elevate their societies.

(C) Najma Al Zidjaly, 2019 (c) commons https://creativecommons.org/licenses/by/4.0/

\section{ACKNOWLEDGEMENT}

I am eternally indebted to David Wilmsen's willingness and ability to provide exact translations of Arabic data (used in this paper and in others), which capture the true essence of what has 
been said in Arabic and make all the difference. I also thank profusely Sage Graham, Miriam Locher, Tatiana Larina, Alla Tovares and an anonymous reviewer for valuable comments on earlier versions of this article.

\section{REFERENCES}

Abdul Sattar, Salasiah Hiba, Che Lah \& Raja Suleiman (2009). A study on strategies used in Iraqi Arabic to refuse suggestions. The International Journal of Language Society and Culture, 30, $81-95$.

Alaoui, Sakina (2011). Politeness principle: A comparative study of English and Moroccan Arabic requests, offers and thanks. European Journal of Social Sciences, 20 (1), 7-15.

Al-Adaileh, Bilal A. (2011). When the strategic displacement of the main topic of discussion is used as a face-saving technique: Evidence from Jordanian Arabic. Journal of Politeness Research, 7, 239-257.

Al-Shlool, Safaa (2016). (Im)politeness and gender in the Arabic discourse of social Media Network Websites: Facebook as a norm. International Journal of Linguistics, 8 (3), 1948-5425.

Al Zidjaly, Najma (2006). Disability and anticipatory discourse: The interconnectedness of local and global aspects of talk. Communication \& Medicine, 3 (2), 101-112.

Al Zidjaly, Najma (2010). Intertextuality and constructing Islamic identities online. In: Rotimi T (ed.) Handbook of research on discourse behavior and digital communication: Language structures and social interaction. New York: IGI Global, 191-204.

Al Zidjaly, Najma (2012). What has happened to Arabs? Identity and face management online. Multilingua, 31, 413-439.

Al Zidjaly, Najma (2014). WhatsApp Omani teachers? Social media and the question of social change. Multimodal Communication, 3 (1), 107-130.

Al Zidjaly, Najma (2015). Disability, discourse and technology: Agency and inclusion in (Inter)action. London: Palgrave Macmillan.

Al Zidjaly, Najma (2017a). Memes as reasonably hostile laments: A discourse analysis of political dissent in Oman. Discourse \& Society, 28 (6), 573-594.

Al Zidjaly, Najma (2017b). Mental health and religion on Islamweb.net. Linguistik Online. http://dx.doi.org/10.13092/lo.87.4178.

Al Zidjaly, Najma (2019a). Digital activism as nexus analysis: A sociolinguistic example From Arabic Twitter. Tilburg Papers in Culture Studies, paper 221.

Al Zidjaly, Najma (2019b). Society in digital contexts: New modes of identity and community construction (Introduction). Multilingua, 38 (4), 357-375.

Al Zidjaly, Najma (Forthcoming in 2020). Multiscale repair as activism on Arabic Twitter. In Gordon, Cynthia (ed.). Approaches to discourse. Washington DC: Georgetown University Press.

Al Zidjaly, Najma \& Cynthia Gordon (2012). Mobile phones as cultural tools: An Arabian example. Intercultural Management Quarterly, 13 (2), 14-17.

Al-Zumor, Abdul Wahed (2011). Apologies in Arabic and English: An inter-language and cross-cultural study. Journal of King Saud University - Languages and Translation, 23 (1), 19—28.

Badarneh, Muhammad A. (2019). 'Like a donkey carrying books': Intertextuality and impoliteness in Arabic online reader responses. Journal of Language Aggression and Conflict. https://doi.org/10.1075/jlac.00027.bad.

Badarneh, Muhammad A \& Fathi Migdadi (2018). Acts of positioning in online reader comments on Jordanian news websites. Language \& Communication, 58, 93-106. 
Bakhtin, Michael (1981). The dialogic imagination. Austin: The University of Texas Press.

Bateman, John (2014). Text and image: A critical introduction to the visual/verbal divide. Abingdon: Routledge.

Beeman, William (1986). Language, status, and power in Iran. Bloomington, IN: Indiana University Press.

Blommaert, Jan (2018). Durkheim and the Internet: On sociolinguistics and the sociological imagination. London: Bloomsbury.

Bou-Franch, Patricia \& Garcés-Conejos Blitvich, Pilar (2018). Relational work in multimodal networked interactions on Facebook. Internet Pragmatics 1:2. 134-160.

Bousfield, Derek (2007). Beginnings, middles, and end: A biopsy of the dynamics of impolite exchanges. Journal of Pragmatics, 39. 2185-2216.

Brown, Penelope \& Steven Levinson (1987). Politeness: Some universals in language use. Cambridge University Press.

Culpeper, Jonathon (1996). Towards an anatomy of impoliteness. Journal of Pragmatics, 25: $349-367$.

Culpeper, Jonathon (2010). Conventionalized impoliteness formulae. Journal of Pragmatics, 42 (12), $3232-3245$.

Culpeper, Jonathon (2011). Impoliteness: Using language to cause offence. Cambridge: Cambridge University Press.

Ebadi, Saman \& Salman, Ahmed Rawdhan (2015). Using compliment responses in Arabic and English: Focusing on male and female EFL learners in Iraq. Journal of Applied Linguistics and Language Research, 2(7): 157-178.

Eickelman, Dale (1989). National identity and religious discourse in contemporary Oman. International Journal of Islamic and Arabic Studies, 6 (1), 1-20.

Eickelman, Dale \& Jon Anderson (2003). New media in the Muslim world: The emerging public sphere. Bloomington: Indiana University Press.

Emery, Peter (2000). Greeting, congratulating and commiserating in Omani Arabic. Language Culture and Curriculum, 13 (2), 196-216.

Farhat, Emdelellah (2013). Gender, power, politeness and women in the Arab society. Journal of English Language \& Translation Studies, 1 (1), 50-60.

Feghali, Ellen (1997). Arab culture communication patterns. International Journal of Intercultural Relations, 21, 345-378.

Garcés-Conejos Blitvich, Pilar (2010). The YouTubification of politics, impoliteness and polarization. In Rotimi T (ed.). Handbook of research on discourse behavior and digita, 134, 120-133.

Garcés-Conejos Blitvich, Pilar, Nuria Lorenzo-Dus \& Patricia Bou-Franch (2013). Relational work in anonymous, asynchronous communication: A study of (dis)affiliation in YouTube. In Kecskes I \& J Romero-Trillo (eds.) Research trends in intercultural pragmatics. Berlin: Mouton de Gruyter, 343-366.

Georgakopoulou, Alexandra (2017). 'Whose context collapse?' Ethical clashes in the study of language and social media in context. Applied Linguistics Review, 8 (2-3), 1-32.

Georgakopoulou, Alexandra \& Tereza Spilioti, (eds.) (2016). The Routledge handbook on language and digital communication. London: Routledge.

Georgakopoulou, Alexandra \& Maria Vasilaki (2018). Small stories and impoliteness in online discussions of the Greek crisis. Internet Pragmatics, 1(2), 215-240.

Giddens, Anthony (1990). The consequences of modernity. Cambridge: Polity.

Goffman, Erving (1967). Interaction ritual: Essays in face-to-face behavior. Chicago, IL: Aldine. 
Graham, Sage L. (2007). Disagreeing to agree: Conflict, (im)politeness and identity in a computermediated community. Journal of Pragmatics, 39 (4), 742-759.

Graham, Sage L. (2008). A manual for (im)politeness? The impact of the FAQ in and electronic community of practice. In Bousfield, D. \& M. Locher (eds.) Impoliteness in language: Studies on its interplay with power in theory and practice. Berlin: Mouton de Gruyter, 281-304.

Graham, Sage L. (2018). Impoliteness and the moral order in online gaming. Internet Pragmatics, 1 (2): $303-328$.

Graham L. Sage \& Scott Dutt (2019). "Watch the potty mouth": Negotiating impoliteness in online gaming. In Ensslin, A. and I. Balteiro (eds.) Approaches to videogame discourse. London: Bloomsbury Academic, 201-223.

Graham, Sage L. \& Claire Hardaker (2017). (Im)politeness in digital communication. In Jonathon Culpeper (ed.). The Palgrave handbook of linguistic (im)politeness, 785-814. London: Palgrave Macmillan.

Hammod, Najla \& Arwa Abdul-Rassul (2017). Impoliteness strategies in English and Arabic Facebook comments. International Journal of Linguistics, 9 (5): 97-112.

Hardaker, Claire (2015). "I refuse to respond to this obvious troll": An overview of (perceived) trolling. Corpora, 10 (2), 201-229.

Haugh, Michael (2015). Im/politeness implicatures. Berlin: Mouton de Gruyter.

Haugh, Michael (2018). Afterword: theorizing impoliteness. Journal of Politeness Research, 14 (1), $153-165$.

Hegland, Michael (1998). Flagellation and fundamentalism: (Trans)forming meaning, identity, and gender through Pakistani women's rituals of mourning. American Ethnologist 25(2), 240-266.

Herring, Susan (2004). Computer-mediated discourse analysis: An approach to Researching online behavior. In Barab, S., R. Kling \& J. Gray (eds.) Designing for virtual communities in the service of learning. New York: Cambridge University Press, 338-376.

Hofstede, Geert (1990). Cultures and organizations: Software of the mind. New York: McGraw-Hill.

Jay, Timothy (1992). Cursing in America: A psycholinguistic study of dirty language in the courts, in the movies, in the school yards and on the streets. Philadelphia: John Benjamins.

Jay, Timothy (2000). Why we curse: A neuro-psycho-social theory of speech. Philadelphia: John Benjamins.

Kádár, Dániel (2017a). Politeness, impoliteness and ritual: Maintaining the moral order in interpersonal interaction. Cambridge: Cambridge University Press.

Kádár, Dániel (2017b). Indirect ritual offence: A study on elusive impoliteness. In Cap, P. and M. Dynel (eds.) Impoliteness: From lexis to discourse. Amsterdam: John Benjamins, 177-199.

Kádár, Dániel \& Michael Haugh (2013). Understanding politeness. Cambridge: Cambridge University Press.

Kádár, Dániel, Michael Haugh \& Chang, Wei-Lin Melody (2013). Aggression and perceived national face threats in Mainland Chinese and Taiwanese CMC discussion boards. Multilingua, 32 (3), $343-372$.

KhosraviNik, Majid (2016). Social media critical discourse studies (SM-CDS). In: Flowerdew F and Richardson J (eds.) Handbook of critical discourse analysis. London: Routledge, 582-596.

KhosraviNik, Majid \& Nadia Sarkhoh (2017). Arabism and anti-Persian sentiments on participatory web platforms: A social media critical discourse study. International Journal of Communication, $11,3614-3633$.

Kristeva, Julia (1980/1967). Word, dialogue and novel. In Roudiez, L.S. (ed.) Desire in language: A semiotic approach to literature and art (T. Gora, A. Jardine\& L.S. Roudiez, Trans.) New York, NY: Columbia University Press, 64-91. 
Labben, Afef (2018). Face and identity in interaction: A focus on Tunisian Arabic. Journal of Pragmatics, 128, 67-81.

Lewis, Bernard (2001). The multiple identities of the Middle East. New York: Schocken Books.

Locher, Miriam A. (2006). Polite behavior within relational work: The discursive approach to politeness. Multilingua, 25, 249-267.

Locher, Miriam A. (2008). Relational work, politeness, and identity. In G. Antos \& E. Ventola (eds., in cooperation with T. Weber). Handbook of interpersonal communication, 509-540. Berlin, Germany: Mouton de Gruyter.

Locher, Miriam A. (2015). Interpersonal pragmatics and its link to (im)politeness research. Journal of Pragmatics, 86, 5-10.

Locher, Miriam A. (2018). Politeness. In Chapelle, C (ed.). The Encyclopedia of Applied Linguistics. London: John Wiley \& Sons, Ltd. DOI: 10.1002/9781405198431.wbeal0916.pub2.

Locher, Miriam A. \& Brook Bolander (2017). Facework and identity. In C.R. Hoffman and W. Bublitz (eds.). Pragmatics of social media, 407-434. Berlin: De Gruyter Mouton.

Locher, Miriam A. \& Sage L Graham (2010). Introduction to interpersonal pragmatics. In Miriam A. Locher and Sage L. Graham, Interpersonal pragmatics, 1-13. Berlin: Mouton de Gruyter.

Locher, Miriam A. \& Richard J. Watts (2005). Politeness theory and relational work. Journal of Politeness Research 1: 92-33.

Mak, Bernie Chun Nam \& Chui, Hin Leung (2014). Impoliteness in Facebook status updates: Strategic talk among colleagues 'outside' the workplace. Text \& Talk, 34 (2), 165-185.

Mazid, Mohammed (2006). (Translating) Emirati Arabic politeness formulas: An exploratory study and a mini-mini-dictionary. The Seventh Annual U.A.E University Research Conference, 76285 .

Mohammed, Hiba N. \& Abbas, Nawal F. (2015). Pragmatics of impoliteness and rudeness. American International Journal of Social Science, 4 (6): 195-205.

Morozov, Evelyn (2011). The net delusion: The dark side of Internet freedom. New York: Public Affairs.

Najeeb, Zena M., Marlyna Maros \& Fariza Mohd Nor (2012). Politeness in E-mails of Arab students in Malaysia. Journal of Language Studies, 12 (1): 125-145.

Nelson, Gayle, Mohamoud Al Batal \& Waguida El Bakary (2002). Directness vs. indirectness: Egyptian Arabic and US English communication style. International Journal of Intercultural Relations, 26: 39-57.

Nishida, Kitarō (1958). Intelligibility and the philosophy of nothingness. Tokyo: Maruzen.

Nordenson, Jon (2018). Online activism in the Middle East. London: Ibtauris.

Reiter, Rosina \& Sara Orthaber (2018). Exploring the moral compass: Denunciations in a Facebook carpool group. Internet Pragmatics, 1 (2), 241-270.

Samarah, Abdullah (2015). Politeness in Arabic culture. Theory and Practice in Language Studies, 5 (10), 2005-2016.

Schegloff, Emanuel A. (2007). Sequence organization in interaction. Cambridge: Cambridge University Press.

Schiffrin, Deborah (1989). Discourse markers. Cambridge: Cambridge University Press.

Scollon, Ron (2001). Mediated discourse: The nexus of practice. London: Routledge.

Sinatora, Francesco (2019a). Chronotopes, entextualization and Syrianpolitical activism on Facebook. In Najma Al Zidjaly (ed.). Society in digital contexts: New modes of identity and community construction. Multilingua, 38 (4): 427-458. 
Sinatora, Francesco (2019b). Language, identity, and Syrian political activism on social media. London: Routledge.

Sinkeviciute, Valeria (2018). "Ya bloody drongo!!!" impoliteness as situated moral judgement on Facebook. Internet Pragmatics, 1 (2), 271-302.

Sumiala, Johanna \& Lilly Korpiola (2017). Mediated Muslim martyrdom: rethinking digital solidarity in the "Arab Spring". New Media \& Society, 19 (1), 52-66.

Tetreault, Chantal (2015). "What do you think about having beauty marks on your - Hashek!": Innovative and impolite uses of an Arabic politeness formula among French teenagers. Journal of linguistic Anthropology, 25 (3), 285-302.

Ting-Toomey, Sue (2004). The matrix of face: An updated face-negotiation theory. In W. Gudykunst (ed.). Theorizing about intercultural communication, 71-92. Thousand Oaks, CA: Sage.

Ting-Toomey, Sue (ed.) (1994). The challenge of facework: Cross-cultural and interpersonal issues. Albany, NY: State University of New York Press.

Tracy, Karen (2008). 'Reasonable hostility': Situation-appropriate face-attack. Journal of Politeness Research, 4, 169-191.

Tovares, Alla (2006). Public medium, private talk: gossip about a TV show as 'quotidian hermeneutics.' Text \& Talk, 26 (4/5), 463-491.

Tovares, Alla (2019). Negotiating "thick" identities through "light" practices: YouTube metalinguistic comments about language in Ukraine. Multilingua, 38 (4), 459-484.

Upadhyay, Shiv R. (2010). Identity and impoliteness in computer-mediated reader responses. Journal of Politeness Research, 6, 105-127.

Vásquez, Camilla (2014). The discourse of online consumer reviews. Indiana: Bloomsbury Publishing.

Watts, Richard (2003). Politeness. Cambridge, UK: Cambridge University Press.

Wilce, John (2005). Traditional laments and postmodern regrets: The circulation of discourse in metacultural context. Journal of Linguistic Anthropology, 15 (1), 602-71.

Xie, Chaoqun (2011). Politeness and memes: Philosophizing pragmatics. Fuzhou: Fujian People's Publishing House.

Xie, Chaoqun (2018). Introduction: (Im)politeness, morality and the internet. Internet Pragmatics, $1(2), 205-214$.

Xie, Chaoqun, Ziran, He \& Lin Dajin (2005). Politeness: Myth and truth. Studies in Language, 29 (2), $431-461$.

Zappavigna, Michelle (2011). Ambient Affiliation: A linguistic perspective on Twitter. New Media \& Society, 13 (5), 788-806.

Zayani, Mohamed (2018). Digital Middle East. Oxford: Oxford University Press.

\section{Article history:}

Received: 21 June 2019

Revised: 12 October 2019

Accepted: 19 October 2019

\section{История статьи:}

Дата поступления в редакцию: 21 июня 2019

Дата принятия к печати: 19 октября 2019 


\section{Bionote:}

NAJMA AL ZIDJALY is Associate Professor in the Department of English Language and Literature at the College of Arts \& Social Sciences (Sultan Qaboos University, Oman). Her research focuses on social media and Arab (Omani) identity (with or without disability). She is the author of Disability, discourse and technology: Agency and inclusion in (inter)action (Palgrave Macmillan, 2015) and the editor of the Special Issue, Society in digital contexts: New modes of identity and community construction (Multilingua, 2019). Al Zidjaly is on the editorial board of the Journal of Multimodal Communication and has additionally published articles in scholarly journals such as Discourse \& Society; Language in Society; Communication \& Medicine; Multimodal Communication; Multilingua; Visual Communication; and Discourse, Context and Media

Contact information: najmaz@gmail.com

\section{Сведения об авторе:}

НАДЖМА АЛЬ ЗИДЖАЛИ - доцент кафедры английского языка и литературы Колледжа гуманитарных и социальных наук (Университет имени Султана Кабуса, Оман), член редколлегии журнала Journal of Multimodal Communication. Ее научные интересы сосредоточены на социальных медиа и арабской (оманской) идентичности. Она является автором книги Disability, discourse and technology: Agency and inclusion in (inter)action (Инвалидность, дискурс и технологии) (Palgrave Macmillan, 2015), редактором специального выпуска журнала Multilingua, посвященного идентичности в цифровом контексте (Multilingua, 2019). Ряд ее статей опубликован в журналах Discourse \& Society; Language in Society; Communication \& Medicine; Multimodal Communication; Multilingua; Visual Communication; Discourse, Context and Media.

Контактная информация: najmaz@gmail.com 